\title{
IMPACT OF SALINITY STRESS ON SEED GERMINATION INDICES OF MAIZE (Zea mays L.) GENOTYPES
}

\author{
Mohammad Muhebbullah Ibne Hoque ${ }^{1 *}$, Zheng $\mathrm{Jun}^{2}$ and Wang Guoying ${ }^{2} *$ \\ ${ }^{1}$ Graduate School of Chinese Academy of Agricultural Sciences (GSCAAS), \\ ${ }^{2}$ Chinese Academy of Agricultural Sciences (CAAS) \\ 12 Zhongguancun South Street, Haidian District, Beijing 100081, P. R. China \\ and \\ ${ }^{1}$ Lal Teer Seed Limited, Anchor Tower \\ 108 Bir Uttam C.R. Dutta Road \\ Dhaka 1205, Bangladesh \\ *Corresponding authors: E-mail: muhibleeibnehoque@gmail.com
}

(Received March 31, 2014)

\begin{abstract}
This investigation was done to find germination response of nine maize (Zea mays L.) genotypes under three levels of $\mathrm{NaCl}$ salinity $(0 \mathrm{mM}, 100 \mathrm{mM}$ and $200 \mathrm{mM})$. Seeds were germinated and grown in Petri plates on filter paper, using above mentioned salt solution as treatment with three replications, incubated at $28 \pm 1{ }^{\circ} \mathrm{C}$ in a growth chamber following randomized complete block design. Germination percentage (GP), germination speed (GS), germination index (GI), seedling dry weight (SDW), seed vigor index (SVI) and salt tolerance index (STI) were all decreased as the level of $\mathrm{NaCl}$ was increased. Mean germination time (MGT) and Percent reduction in dry weight over control (\%ROC) was increased as the $\mathrm{NaCl}$ levels increased. Interaction between genotypes and salt levels showed varying degree of differences. It is concluded that genotypes showed response variability for seed germination under saline stress. Among the investigated genotypes inbred line CZ-7 expressed as the tolerant genotype and B73 appeared to be more sensitive at germination stage.
\end{abstract}

\section{INTRODUCTION}

Maize, (Zea mays L.) belonging to the family Poaceae is the third largest cereal crops after rice and wheat. It is widely cultivated and grown approximately 177 million hectares all over the world in 2012 with a total production of 875 million tons (FAOSTAT, 2013). It has become one of the global food security crops due to its growing ability in various soils and climates.

Global food production will need to increase by $38 \%$ by 2025 and by $57 \%$ by 2050 (WILD, 2003) if food supply to the growing world population is to be maintained at current levels. The global climate change is feared to promote rapid soil degradations in agricultural lands worldwide. Soil salinization is one of the serious soil degradations, which can arise from natural causes and human-mediated activity such as irrigation in arid and semi-arid regions (HORIE, et al., 2012). Salinization of soil is one of the major factors limiting crop production particularly in arid and semi-arid regions of the world (AHMED, 2009). Most crops are sensitive to salinity caused by high concentration of salts in the soil. It is a global problem and a major threat to irrigated agriculture (VIJAYVARGIYA and KUMAR, 2011). Generally, soils having above 
$4 \mathrm{dS} / \mathrm{m}$ electrical conductivity (EC) of $\mathrm{Na}^{+}$ions (US SALINITY LABORATORY STAFF, 1954) corresponding to $40 \mathrm{mM} \mathrm{NaCl}$ (IRRI, 2011; MUNNS and TESTER, 2008) are defined as saline soil. Usually, saline soils are found in arid regions, estuaries, and coastal fringes. Saline soil inhibits plant growth by affecting osmosis. It reduces the water uptake ability of plants, and thus by ionexcess, eventually affecting the plant cells (MUNNS, 2002). It also induces nutritional imbalances in plants.

Plants, having the ability to grow under salinity are halophyte (QU et al., 2008), while unable plants are called glycophytes (UNGAR, 1991). Glycophytes covers the majority of agricultural products, and growth and production of this plants group are significantly reduced by salinity stress (HORIE et al., 2012). Salt stress is known to perturb a multitude of physiological processes (NOREEN and ASHRAF, 2008). Osmotic stress (drought problem), ion imbalances, particularly with $\mathrm{Ca}$ and $\mathrm{K}$, and the direct toxic effects of ions on the metabolic process are the most important and widely studied physiological impairments caused by salt stress (ZHU, 2001). Like other abiotic stress, it induces oxidative damage to plant cells (AZEVEDO-NETO et al., 2006).

Seed germination is also severely affected by salinity (SHOLI, 2012). Increased salinity caused a significant reduction in germination percentage, germination rate, and root and shoots length and fresh root and shoots weights (JAMIL et al., 2006). Several studies have investigated the effects of the salinity on maize crop, and found that the effect was genotype specific (ZHANG and ZHAO, 2011). Usually, maize is a salt-sensitive crop (MAAS and HOFFMAN, 1977). The response of maize to salinity varies depending on the stage of development (MAAS et al., 1983). Vegetative growth stage appeared to be more sensitive than any other growing stages (CRAMER, 1994).

The development of salt tolerant cultivars has been proposed as the most effective strategy to overcome this problem (EPSTEIN and RAINS, 1987). Selection and breeding of salt tolerant plants is becoming one option to minimize the negative impact of salinity (EPSTEIN $e t$ al., 1980). This could be done at different crop growth stages i.e. crop establishment (germination, emergence and seedling growth), vegetative growth and grain filling.

This study was conducted to evaluate the effect of salinity on seed germination of nine maize genotypes under salinity conditions. The primary objective of the present study was to compare germination ability of nine maize genotypes under salinity stress and to select salt tolerant line of maize which can be used for further breeding programme.

\section{MATERIALS AND METHODS}

\section{Plant Materials}

In this study nine maize genotypes were used to evaluate the degree of salt tolerance at germination stage. Among the nine genotypes eight genotypes were collected from Bangladesh Agricultural Research Institute (BARI), of them three are inbred lines and five are cultivated variety; and other one - a highly popular US inbred line B73 obtained from Chinese Academy of Agricultural Sciences (CAAS), Beijing, China.

\section{Methods}

This study was a laboratory-conducted experiment and carried out in Institute of Crop Science, Chinese Academy of Agricultural Sciences (CAAS) in China, 2011. The seeds were surface sterilized by dipping the seeds in $1.5 \%(\mathrm{v} / \mathrm{v})$ Sodium Hypochloride solution for 10 minutes and rinsed thoroughly with sterile distilled water. There were three salinity treatments i.e. $0 \mathrm{mM}$ (control), $100 \mathrm{mM}$, and $200 \mathrm{mM} \mathrm{NaCl}$. These treatments were prepared by dissolving separately calculated amounts of $\mathrm{NaCl}$ in deionizer water. All the experiments were conducted in $15 \mathrm{~cm}$ diameter sterile Petri plate on filter paper beds in growth chambers. 30 seeds were sown in each Petri plate on filter paper beds, irrigated with $15 \mathrm{ml}$ solution of respective treatment and 
incubated at $28 \pm 1{ }^{\circ} \mathrm{C}$ for 10 days. The humidity of the growth chamber was maintained at $65 \%$. Each treatment had three replications. The filter paper beds were irrigated daily with $5 \mathrm{ml}$ solution of the respective treatments. The filter beds were changed with the new one after $48 \mathrm{hrs}$ in order to avoid salt accumulation.

\section{Data Measurement}

The emergence of plumule was recorded daily up to ten days as index of germination (CARPICI et al., 2009). The dry weights of the shoots and roots of the seedlings were measured at 10 days after the experiment started. The dry weights were measured after drying the shoot and root at $80^{\circ} \mathrm{C}$ for $48 \mathrm{hrs}$. Based on that information following measurements were calculated.

Germination percentage (GP): GP $=(\mathbf{S N G} / \mathrm{SN0}) \times \mathbf{x 1 0 0}, \mathrm{SNG}=$ number of germinated seeds, SN0 = number of experimental seeds with viability (LI, 2008).

Germination speed (GS): $\mathbf{G S}=\mathbf{\Sigma} \mathbf{D} \times \mathbf{n} / \mathbf{\Sigma} \mathbf{n}, \mathrm{n}=$ number of germinated seeds at each day; D = number of days after the start of the experiment (LI, 2008)

Germination index $(\mathbf{G I})$ : $\mathbf{G I}=\sum(\mathbf{G t} / \mathbf{T t}), \mathrm{Gt}=$ number of seeds germinated on th day, $\mathrm{Tt}=$ number of days up to th day (LI, 2008).

Mean germination time (MGT): MGT $=\Sigma \mathrm{TiNi} / \Sigma \mathrm{Ni}, \mathrm{Ni}=$ number of the newly germinated seeds in times of $\mathrm{Ti}$ (HU et al., 2005).

Seed vigour index (SVI): SVI = SDW/MGT, MGT = mean germination time, SDW = seedling dry weight (ELLIS and ROBERTS, 1980).

Salt tolerance index (STI): STI $=($ TDW at Sx/TDW at S1) $\mathbf{x 1 0 0 ,}$ TDW = total dry weight, $\mathrm{S} 1=$ control treatment, $\mathrm{Sx}=$ salt level treatment (SEYDI, 2003).

Dry weight reduction over control $($ ROC $):(\%$ ROC $)=\{($ value in control - value in saline environment)/value in control $\} \times 100$ (ALI et al., 2004).

\section{Statistical Analysis}

The experiment was conducted following randomized complete block design with 3 replications. Data were subjected to statistical analysis using ANOVA, a statistical package available from SPSS16. Significant differences between treatments were determined using LSD test at the 0.05 level.

\section{RESULTS}

The results of ANOVA manifested that the measured components of maize genotypes were significantly affected by salt concentrations except interaction between genotype and salinity in case of mean germination time (Table 1). In general, salt stress adversely affected germination of maize genotypes.

Table 1. Analysis of variance of the traits determined.

\begin{tabular}{|c|c|c|c|c|c|c|c|c|}
\hline \multirow{2}{*}{$\begin{array}{c}\text { Source of } \\
\text { variation }\end{array}$} & \multirow[t]{2}{*}{ df } & \multicolumn{7}{|c|}{ Mean Square } \\
\hline & & GP & GS & GI & MGT & SDW & SVI & STI \\
\hline Genotype (G) & 8 & $2490.742 * * *$ & $178.485^{* * *}$ & $610.958 * * *$ & $0.146^{* * *}$ & $0.00023 * * *$ & $5.054 \mathrm{E}-6 * * *$ & $1493.300 * * *$ \\
\hline Salinity (S) & 2 & $6538.273 * * *$ & $698.130 * * *$ & 4520.733 *** & $1.635 * * *$ & $0.005 * * *$ & $0.00015 * * *$ & $11960.616 * * *$ \\
\hline $\mathbf{G} \times \mathbf{S}$ & 16 & $614.197 * * *$ & $41.860 * * *$ & $121.299 * * *$ & $0.047^{\mathrm{NS}}$ & $0.00034 * * *$ & $8.868 \mathrm{E}-6^{* * *}$ & $426.733 * * *$ \\
\hline Error & 54 & 61.591 & 5.418 & 13.993 & 0.029 & 7.392E-6 & $1.847 \mathrm{E}-7$ & 11.860 \\
\hline CV (\%) & & 28.95 & 29.07 & 35.08 & 4.58 & 34.24 & 72.46 & 30.34 \\
\hline
\end{tabular}

NS Not significant; *** significant at the 0.001 level of probability; GP: Germination percentage; GS: Germination speed; GI: Germination Index; MGT: Mean germination time; SDW: Seedling dry weight; SVI: Seed vigour index; STI: Salt tolerance index.

According to the results, germination percent was significant in 0.001 percentages for salt levels, genotypes and interaction between salt levels and genotypes. At different salt 
concentrations, CZ-7 and B73 had the highest and lowest germination percentage as 97.00 and $41.50 \%$, respectively. Inbred line $\mathrm{CZ}-10$ had the second highest germination percentage (91.90\%). At different levels of $\mathrm{NaCl}$ concentration, $\mathrm{CZ}-7$ demonstrated better tolerance to salt stress than other genotypes for germination percentage (Figure 1).

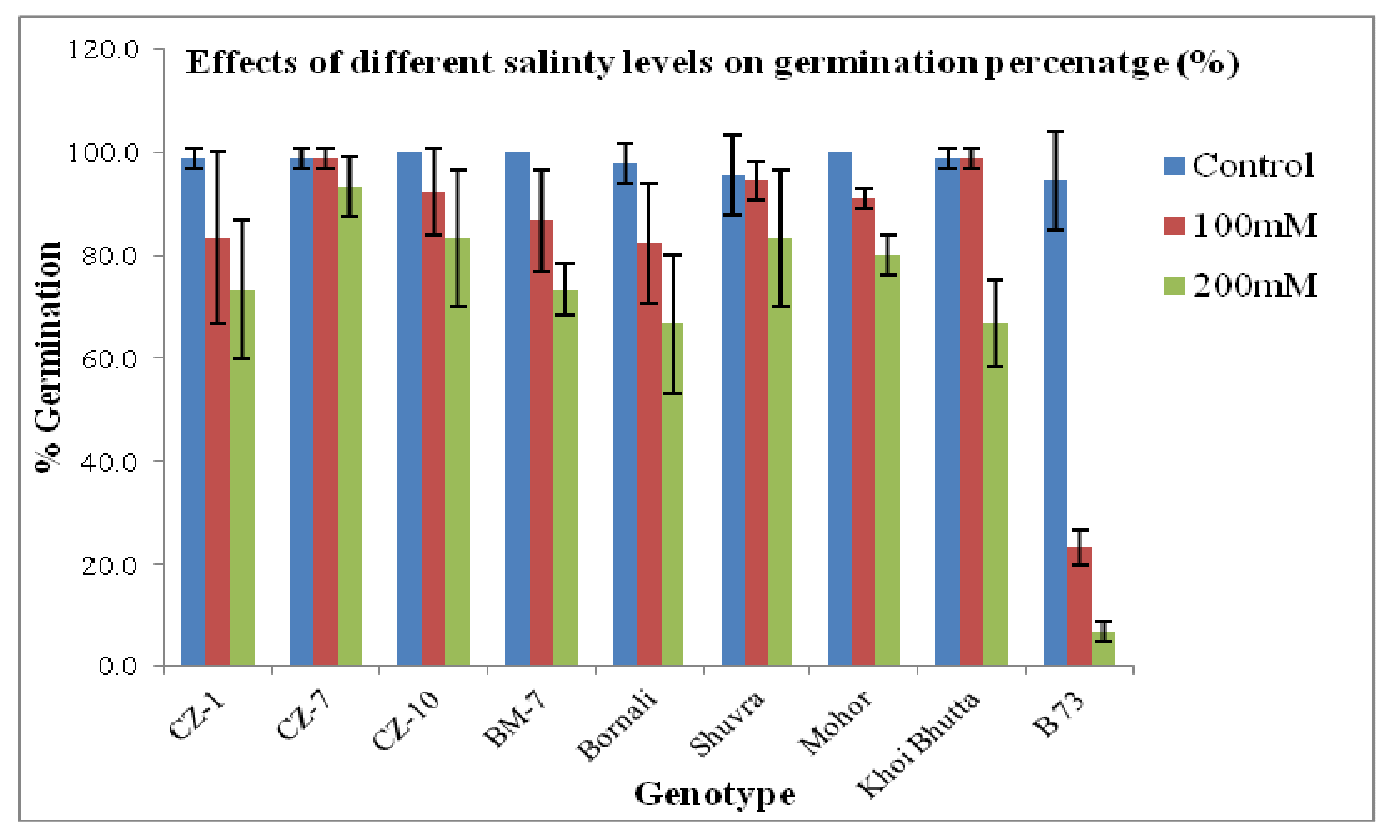

Fig. 1. Effects of different salinity levels on germination percentage (\%).

The results showed that germination speed of these maize genotypes were significantly affected by different concentration of salts $(\mathrm{p}<0.001)$ (Table 1). Speed of germination was reduced by salinity by $12.95 \%$ in CZ-7 and by $95.93 \%$ in B73 at highest level $(200 \mathrm{mM})$ of $\mathrm{NaCl}$ (Figure 2).

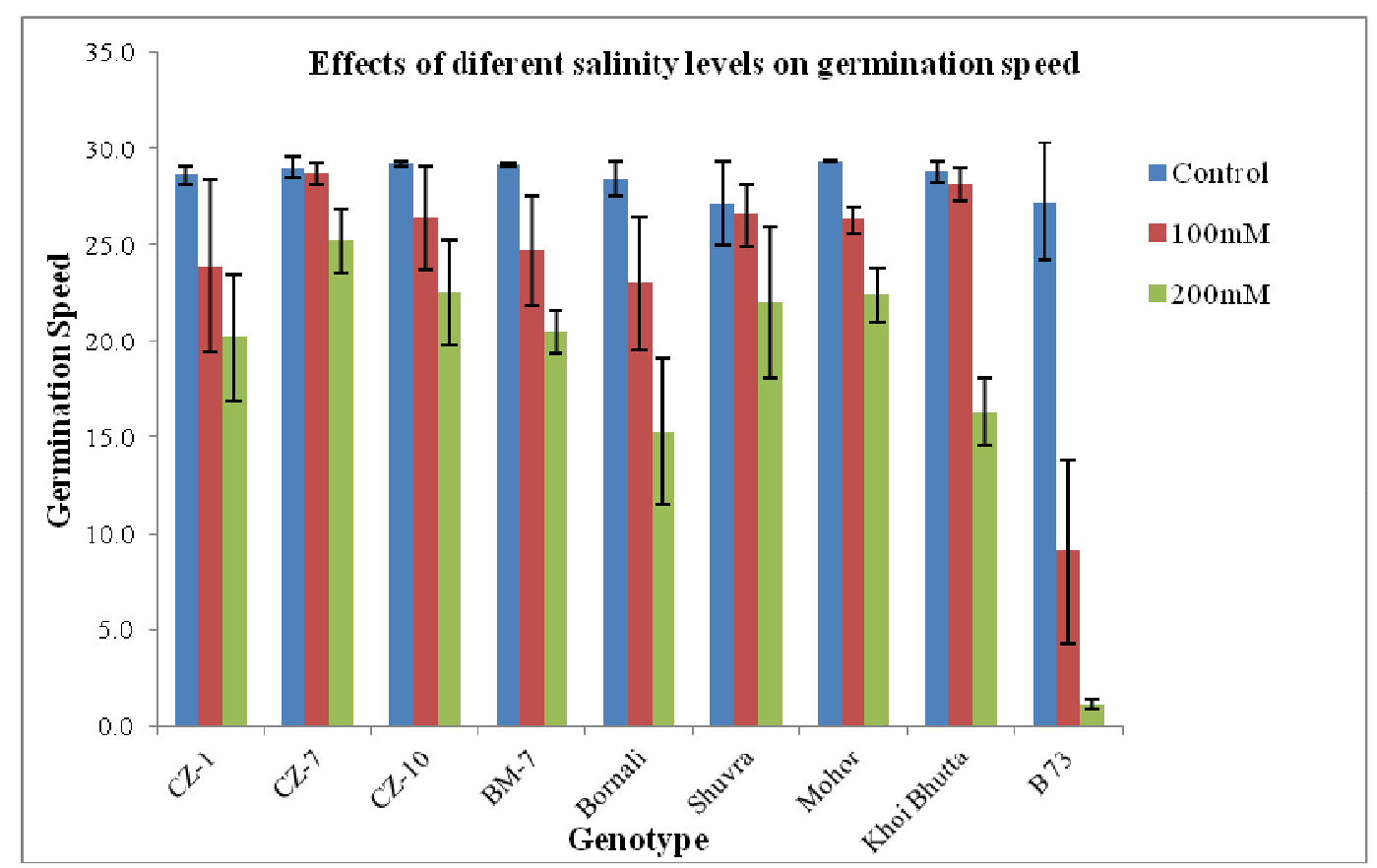

Fig. 2. Effects of different salinity levels on speed of germination. 
Among the nine maize genotypes, the highest germination index (GI) value was recorded for CZ-7 (45.07) and lowest for B73 (1.54) recorder at maximum salt stress condition (200 mM), and comparing to the control only minimal decline $(18.05 \%)$ was recorded for CZ-7 under highest salinity stress and maximum decline (96.94\%) was observed in B73. Mean GI values were 53.51 in control conditions and 27.69 under salt stress $(200 \mathrm{mM})$. Overall $48.26 \%$ decline in GI with salinity was recorded (Figure 3).

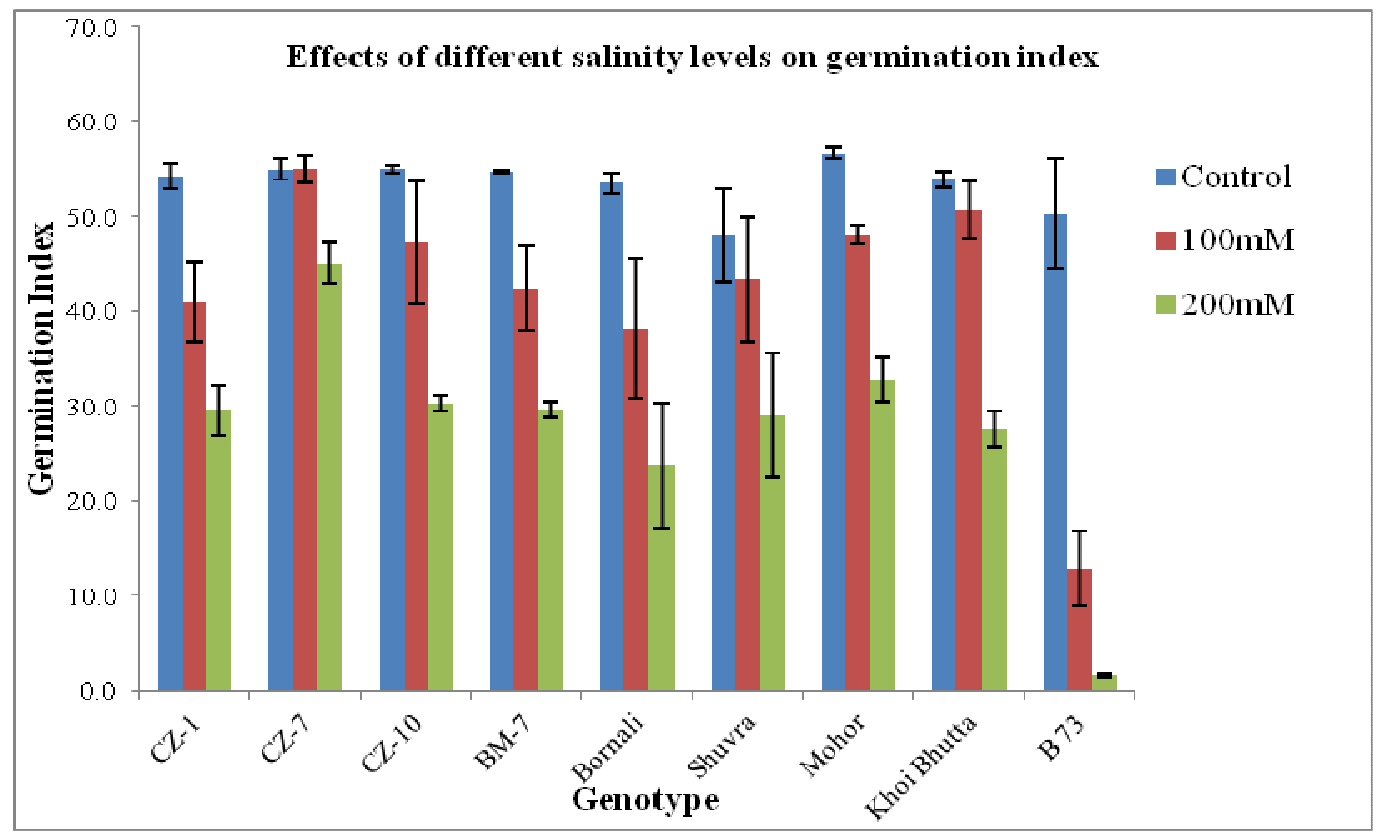

Fig. 3. Effects of different salinity levels on germination index.

Salinity also had considerable effect on germination time of maize seeds, as evident from different germination time delay among the genotypes. CZ-7 had the fastest germinating seeds: 6.21 days (Figure 4). Germination time dramatically increased with salt stress. Mean values of MGT were 6.11 in control conditions and 6.59 under salt stress $(200 \mathrm{mM})$. Overall $7.39 \%$ increase in MGT with salinity was recorded (Figure 4).

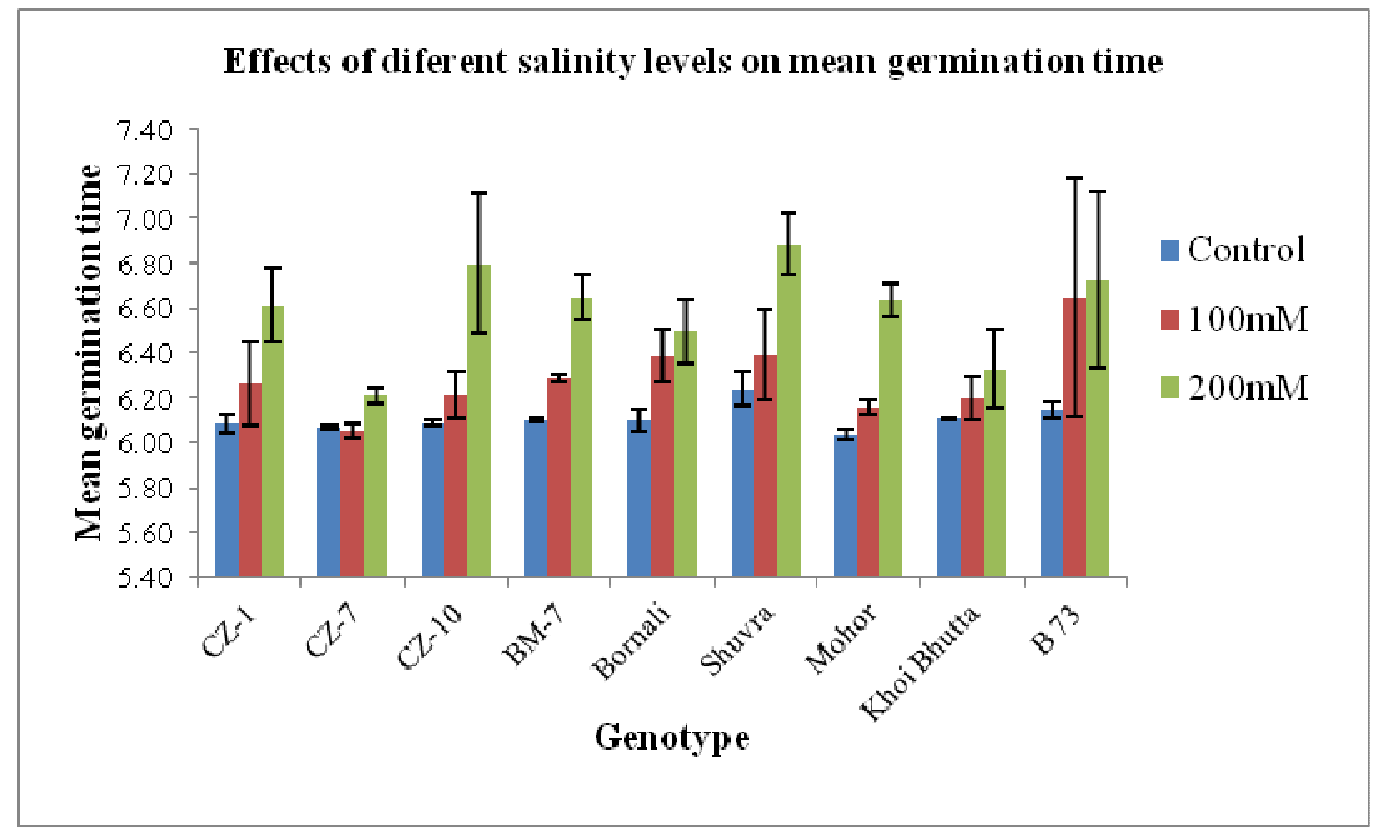

Fig. 4. Effects of different salinity levels on mean germination time. 
Seeding dry weight of genotypes decreased significantly as the levels of salinity increased from 0 to $200 \mathrm{mM} \mathrm{NaCl}$. Thus, the highest seedling dry weight was found in the control and the lowest root dry weight at the highest salinity level. Among the genotypes, CZ-7 was affected least by salinity. The rate of reduction in seedling dry weight at $200 \mathrm{mM} \mathrm{NaCl}$ in comparison with the control was detected in CZ-1 as 40.43\%, CZ-7 as 6.02\%, CZ-10 as 38.43\%, BM-7 as $41.12 \%$, Bornali as $42.20 \%$, Shuvra as $43.75 \%$, Mohor as 30.83 , Khoi Bhutta as $34.67 \%$ and B73 as $92.18 \%$ (Figure 5).

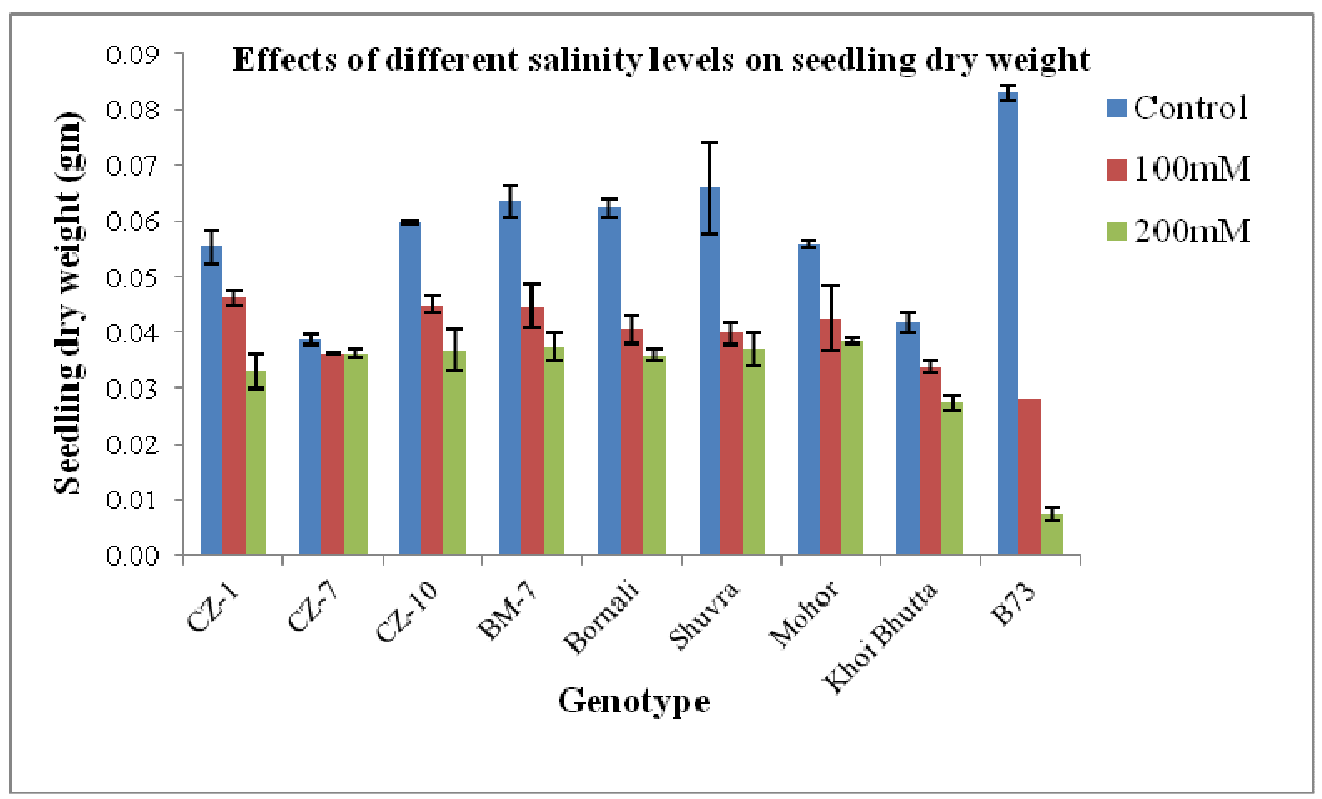

Fig. 5. Effects of different salinity levels on seedling dry weight.

Results of Analysis of Variance for traits seed vigor index showed that there were significant differences between cultivars of these parameters (Table 1). Seed vigor index decreased due to the increased salinity levels from $0 \mathrm{mM}$ to $200 \mathrm{mM} \mathrm{NaCl}$. At the highest salinity $(200 \mathrm{mM})$ level the maximum seed vigor index observed in CZ-7 and the minimum vigor index was found in B73 (Figure 6).

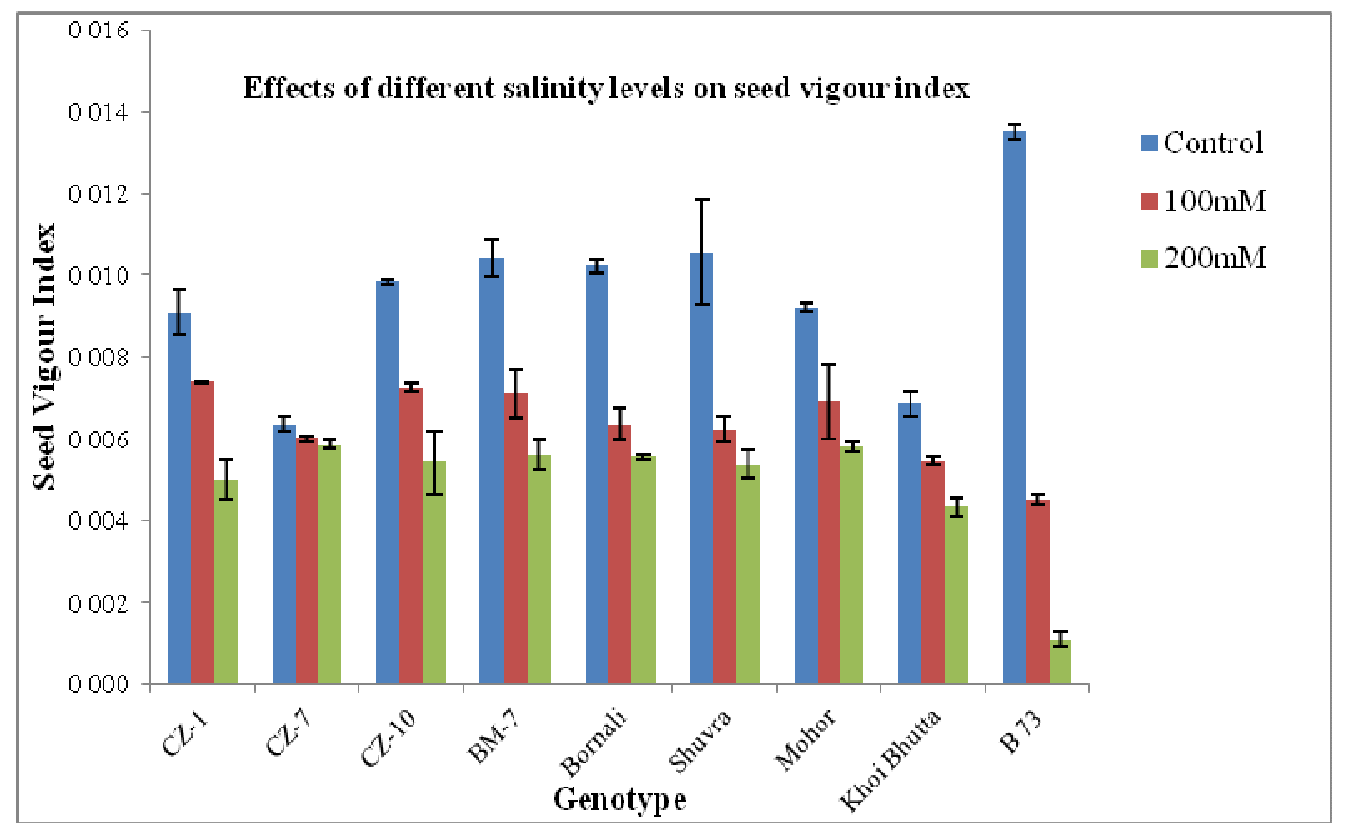

Fig. 6. Effects of different salinity levels on seed vigor index. 
From the results it seems that the effects of $\mathrm{NaCl}$ on salt tolerance index of different maize genotypes was significant (Table 1). The ranges of mean salt tolerance indices among concentrations were very wide ranging from 71.11 at $100 \mathrm{mM}$ of $\mathrm{NaCl}$ to 59.04 at $200 \mathrm{mM}$ of $\mathrm{NaCl}$. The interaction effects of salinity and genotypes were significant for all trials. The highest salt tolerance index was recorded for CZ-7; 94.09 at $100 \mathrm{mM}$ and 93.98 at $200 \mathrm{mM}$ of $\mathrm{NaCl}$. The lowest index was at B73; 33.74 at $100 \mathrm{mM}$ and 8.82 at $200 \mathrm{mM}$ of $\mathrm{NaCl}$ (Figure 7).

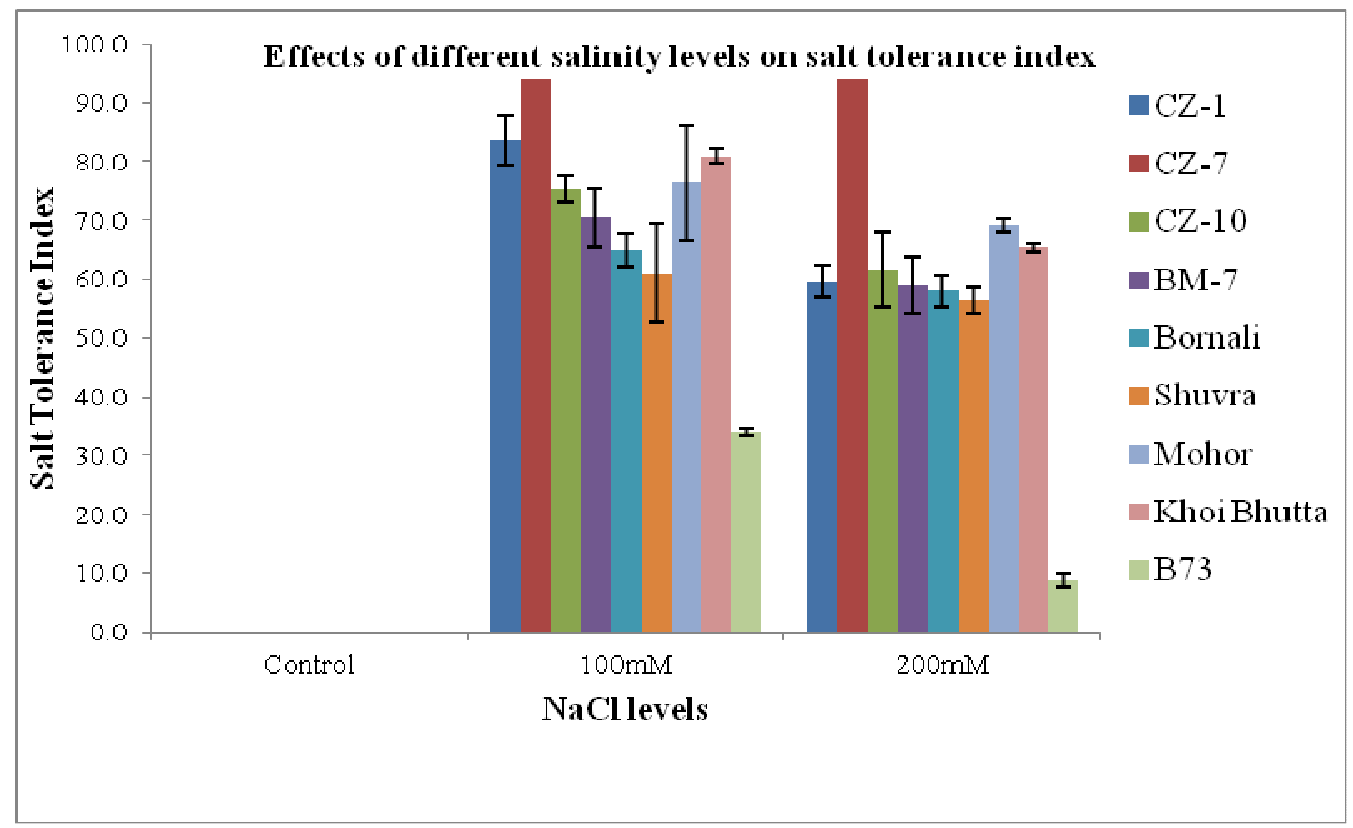

Fig. 7. Effects of different salinity levels on salt tolerance index.

Percent reduction over control results (Table 2) show that as the levels of $\mathrm{NaCl}$ increased the reduction in dry weight increased also. The $200 \mathrm{mM}$ of $\mathrm{NaCl}$ gave the highest reduction $(40.96 \%)$ followed by the $100 \mathrm{mM}$ of $\mathrm{NaCl}(28.89 \%)$. However, different genotypes showed significant differences in percent reduction over control. CZ-7 demonstrated lowest reduction and B73 showed maximum reduction in all salinity levels.

Table 2. Effects of $\mathrm{NaCl}$ salinity on percent reduction over control (\%) of nine maize genotypes.

\begin{tabular}{lccc}
\hline \multirow{2}{*}{ Genotype } & \multicolumn{3}{c}{ Levels of NaCl salinity } \\
\cline { 2 - 4 } & $\mathbf{1 0 0} \mathbf{~ m M}$ & $\mathbf{2 0 0} \mathbf{~ m M}$ & Mean \\
\hline CZ-1 & 16.43 & 40.43 & 28.43 \\
CZ-7 & 5.98 & 6.02 & 6.00 \\
CZ-10 & 24.79 & 38.43 & 31.61 \\
BM-7 & 29.67 & 41.12 & 35.40 \\
Bornali & 35.06 & 42.20 & 38.63 \\
Shuvra & 39.01 & 43.75 & 41.38 \\
Mohor & 23.69 & 30.83 & 27.26 \\
Khoi Bhutta & 19.09 & 34.67 & 26.88 \\
B73 & 66.26 & 91.18 & 78.72 \\
Mean & 28.89 & 40.96 & \\
LSD5\% for NaCl levels=7.22; for cultivars=5.31; for \\
interactions=6.08
\end{tabular}




\section{DISCUSSION}

Germination begins with the imbibition or uptake of water. Salinity prevents water imbibition, thereby hindering the initial process of seed germination (OTHMAN, 2005). Salinity imposes osmotic stress by accumulation of $\mathrm{Na}$ and $\mathrm{Cl}$ ions. In addition, high absorption of $\mathrm{Na}$ and $\mathrm{Cl}$ ions during seed germination can be due to cell toxicity that finally inhibits or slows the rate of germination and thus decreases germination percentage (TAIZ and ZEIGER, 2002). RAHMAN et al., (2000) reported that maize cultivars were significantly more tolerant to salt stress at germination than at later stages of growth. Previous studies have shown that increase in salinity delays the initiation of germination leading to reduction in germination percentage (ABBAD et al., 2004). The present results noticeably show that $\mathrm{NaCl}$ decreased seed germination significantly with the increment of its concentration. Our results are similar to the findings reported by LI (2008). In maize comparable results were reported by ZHANG and ZHAO (2011).

The speed of germination was decreased significantly in all maize genotypes as the salinity levels increased. The reduction of speed of germination at high salt levels might be mainly due to osmotic stress (HEENAN et al., 1988). The decreasing tendency of germination speed due to increasing salinity was in the conformity with the reports of others (ANBUmAlarmathi and MeHTA, 2013).

Increasing salinity of the seed sown and the highest reduction germination index were significant at higher salinity. NASERI et al., (2012) in barley showed that the germination index decreased with increasing salinity. Similar result was also observed by TANVEER et al., (2013) in field bindweed and CARPICI et al., (2009) and ZHANG and ZHAO (2011) in maize and ABBAS et al., (2013) in rice.

In the present study, seed germination time was delayed by salt. Increase of mean germination time (MGT) indicates that germination is delayed comparatively (HAKIM et al., 2011). The increase in MGT with the increasing $\mathrm{NaCl}$ stress was also supported by $\mathrm{XU}$ et al., (2011). Similar result was also observed by REDONDO-GOMEZ et al., (2008), where MGT of Limonium emarginatum was higher in salt stress condition.

With increasing salinity in all nine maize genotypes seed mass seedling dry weight decreased significantly. This result comes in consistent with previous ones (CARPICI et al., 2010). THEERAKULPISUT et al., (2005) stated that the weight of shoots and roots showed high correlation with the level of salinity. ASHRAF (2002) mentioned that the reduction in seedling fresh and dry weight is due to decreasing water uptake by seedlings in salt stress presence. Our results are also similar to the findings reported by RASTEGAR and KANDI (2011) in soybean and by ASHRAF and WAHID (2000) in corn.

In all nine maize genotypes, seed vigor decreased with increasing salinity levels (Figure 6). Generally, seed vigor index is related to special impact of ions and reduction of environmental water potential in the presence of salinity (KESHAVARZI et al., 2011). This is according reports by other researchers. COKKIZGIN (2012); Such KHODARAHMPOUR (2011) and MENSUH et al., (2006) that had been stated vigor reduced by salinity stress.

The salt tolerance indices of genotypes at the germination stage showed a large genotypic variation. The effects of different salinity levels on salt tolerance indices of genotypes were of importance. As the salt concentrations increased the salt tolerance indices of genotypes decreased. Therefore, the lowest value of salt tolerance index was determined at $250 \mathrm{mM} \mathrm{NaCl}$ (Figure 7). Finally, salt tolerance index indicated CZ-7 to be relatively salt tolerant as compared to the other genotypes. Similar results were reported by CARPICI et al., (2009) in maize and ZAIF et al., (2009) in hot pepper.

Seed germination is the most important phase for the growth and development of a plant. Salt content is one of the vital features of soil and should be a primary concern when growing 
any plants. The reason is that salt can dramatically affect plant's growth in all its life stages, from seed to maturity to decline and death. In the current study, the best level of salinity for all investigated traits was control. In general, salt stress adversely affected germination of all maize genotypes. It was noticeable that increasing concentration of $\mathrm{NaCl}$ reduced germination percentage, speed of germination, germination index, seedling dry weight and salt tolerance index significantly. In this study, CZ-7 was the most tolerant inbred line while B73 was the least tolerant among the tested genotypes. These genotypes could be used later for any breeding program from improvement of maize for salt tolerance. Nonetheless, criteria such as germination indices and salt tolerance index could be used as physiological markers for assessing salt tolerance in maize.

\section{References:}

[1] Abbad, A., Hadrami, E.L.A., Benchabane, A. (2004): Germination responses of the Mediterranean Saltbush (Atriplex halimus L.) to NaCl Treatment. J. Agron. 3 (2): 111-114.

[2] Abbas, M.K., Ali, A.S., Hasan, H.H., Ghal, R.H. (2013): Salt Tolerance Study of Six Cultivars of Rice (Oryza sativa L.) During Germination and Early Seedling Growth. $J$. Agril. Sci. 5 (1): 250-259.

[3] Ahmad, S. (2009): Effect of soil salinity on the yield and yield components of Mungbean. Pak. J. Bot. 4 (1): 263-268.

[4] Ali, Y., Aslam, Z., Ashraf, M.Y., TAhiR, G.R. (2004): Effect of salinity on chlorophyll concentration, leaf area, yield and yield components of rice genotypes grown under saline environment. Intern. J. Envir. Sci. Technol. 1 (3): 221-225.

[5] Anbumalarmathi, J., Mehta, P. (2013): Effect of Salt Stress on Germination of indica Rice Varieties. EJBS 6: 1.

[6] AshraF, M. (2002): Evaluation of genetic variation for improvement of salt tolerance in spring wheat. In: Ahmed, R. and MALiK, K.A. (Eds.) Prospects for Saline Agriculture, Netherlands, Kluwer Academic Publisher: 131-137.

[7] Ashraf, M., WAHID, S. (2000): Time course changing in organic metabolites and mineral nutrients in germination maize seeds under salt ( $\mathrm{NaCl})$. Seed Sci. and Techn. 28: 641-656.

[8] Azevedo-Neto, D.D., Prisco, J.T., Eneas, J., Abreu, D.E.C.E.B., Gomes, E. (2006): Effect of salt stress on antioxidative enzymes and lipid peroxidation in leaves and roots of salt-tolerant and salt sensitive maize varieties. Environ. Exp. Bot. 56: 87-94.

[9] CARPICI, E. B., CeliK, N., Bayram, G. (2009): Effects of salt stress on germination of some maize (Zea mays L.) cultivars. Afr. J. Biotechnol. 8 (19): 4918-4922.

[10] Carpici, E.B., Necmettin, C., Gamz, B., Bulen, B.A. (2010): The effects of salt stress on the growth, biochemical parameter and mineral element content of some maize (Zea mays L.) cultivars. Afr. J. Biotechnol. 9 (41): 6937-6942.

[11] Cokkizgin, A. (2012): Salinity Stress in Common Bean (Phaseolus vulgaris L.) Seed Germination. Not Bot Horti Agrobo. 40 (1): 177-182.

[12] Cramer, G.R. (1994): Response of maize (Zea mays L.) to salinity. In: PesSAKLI, M. (Ed.) Handbook of Plant and Crop Stress, Marcel Dekker, New York: 449-59

[13] Ellis, R.H., RoberTs, E.H. (1980): Towards rational basis for testing seed quality. In: HebBlethwaite, P.D. (Ed.) Seed Production. Butterworths, London: 605-635. 
[14] Epstein, E., Norlyn, J.D., Rush, D.W., Kinsbury, R.W., Kelly, D.B., Cunningham, G.A., WronA, A.F. (1980): Saline culture of crops: A genetic approach. Sci. 210: 399-404.

[15] EPSTEIn, E., RAINS, D. (1987): Advances in salt tolerance. Plant \& Soil, 99: 17-29.

[16] FAOSTAT (2013): FAO Statistics Division. Accessed on 11 October 2013.

[17] Hakim, M.A., Juraimi, A.S., Hanafi, M.M., Selamat, A., Ismail, M.R., Karim, S.M.R. (2011): Studies on seed germination and growth in weed species of rice field under salinity stress. J. Environ. Biol. 32: 529-536.

[18] HeEnAN, D.P., LEWIN, L.G., MCCAFFERY, D.W. (1988): Salinity tolerance in rice varieties at different growth stages. Aust. J. Exp. Agric. 28: 343-349.

[19] Horie, T., Karahara, I., Katsuhara, M. (2012): Salinity tolerance mechanisms in glycophytes: An overview with the central focus on rice plants. Rice, 5: 11. Doi:10.1186/1939-8433-5-11.

[20] Hu, J., ZHU, Z.Y., Song, W.J., WANG, J.C., HU, W.M. (2005): Effects of sand priming on germination and field performance in direct-sown rice (Oryza sativa L.). Seed Sci. Technol. 33: $243-248$.

[21] IRRI (2011): Stress and disease tolerance: 1. Breeding for salt tolerance in rice. http://www.knowledgebank.irri.org/ricebreedingcourse/bodydefault.htm\#breeding_for_salt _tolerance.htm

[22] Jamil, M., LeE, D.B., Jung, K.Y., Ashraf, M., LeE, S.C., RhA, S.E. (2006): Effect of salt $(\mathrm{NaCl})$ stress on germination and early seedling growth of four Vegetable species. $J$. Central Eur. Agric. 7 (2): 273-282.

[23] Keshavarzi, M.H.B., Rafsanjani, M.S.O., Moussavinik, S.M., LaK, A.P. (2011): Effect of salt $(\mathrm{NaCl})$ stress on germination and early seedling growth of Spinach (Spinacia oleracea L.). Ann. Biol. Res. 2 (4): 490-497.

[24] Khodarahmpour, Z., Ifar, M., Motamedi, M. (2012): Effects of NaCl salinity on maize (Zea mays L.) at germination and early seedling stage. Afr. J. Biotechnol. 11 (2): 298-304.

[25] LI, Y. (2008): Effect of salt stress on seed germination and seedling growth of three salinity plants. Pak. J. Biol. Sci. 11: 1268-1272.

[26] MaAs, E.V., Hoffman, G.J. (1977): Crop salt tolerance-current assessment. J. Irrig. Drain. E-ASCE. 103 (IR2) I: 15-1.34.

[27] Maas, E.V., Hoffman, G.J., Chaba, G.D., Poss, J.A. Shanon, M.C. (1983): Salt sensitivity of corn at various growth stages. Irrig. Sci. 4: 45-57.

[28] Mensuh, J.K., Akomeah, P.A., Ikhajiagbe, B.E., EkPekurede, O. (2006): Effects of salinity on germination, growth and yield of five ground nut genotypes. Afr. J. Biotechnol. 5 (20): 1973-1979.

[29] Munns, R. (2002): Comparative physiology of salt and water stress. Plant Cell Environ. 25: $239-250$.

[30] Munns, R., Tester, M. (2008): Mechanisms of salinity tolerance. Annu Rev Plant Biol. 59: 651-681.

[31] Naseri, R., Emami, T., Mirzaei, A., Soleymanifard, A. (2012): Effect of salinity (sodium chloride) on germination and seedling growth of barley (Hordeum vulgare L.) cultivars, Intl J Agri Crop Sci. 4 (13): 911-917. 
[32] NoreEn, S., AsHraf, M. (2008): Alleviation of adverse effects of salt stress on sunflower (Helianthus annuus L.) by exogenous application of salicylic acid: Growth and photosynthesis. Pak. J. Bot. 40 (4): 1657-1663.

[33] Othman, Y. (2005): Evaluation of Barely Cultivars Grown in Jordan for Salt tolerance. Jordan University of Science and Technology. PhD Thesis.

[34] Qu, X.X., HuAng, Z.Y., BASKIn, J.M., BASKIN, C.C. (2008): Effect of Temperature, Light and Salinity on Seed Germination and Radicle Growth of the Geographically Widespread Halophyte Shrub Halocnemum strobilaceum. Ann. Bot. 101 (2): 293-299.

[35] Rahman, M., Kayani, S.A., Gul, S. (2000): Combined Effects of Temperature and Salinity Stress on Corn Sunahry Cv., Pak. J. Biological Sci. 3 (9): 1459-1463.

[36] RASTEGAR, Z., KANDI, M.A.S. (2011): The effect of salinity and seed size on seed reserve utilization and seedling growth of soybean (Glycin max), Intl. J. Agrn. Plant Prod. 2 (1): 14.

[37] Redondo-Gomez, S., Mateos Naranjo, E., Garzon, O., Castillo, J.M., Luque, T., FIGUEROA, M.E. (2008): Effects of salinity on germination and seedling establishment of endangered Limonium emarginatum (Willd.) O. Kuntze. J. Coastal Res. 24: 201-205.

[38] SEYDI, A.B. (2003): Determination of the salt tolerance of some barley genotypes and the characteristics affecting tolerance. Turk J. Agric. 27: 253-260.

[39] Sholi, N.J.Y. (2012): Effect of Salt Stress on Seed Germination, Plant Growth, Photosynthesis and Ion Accumulation of four Tomato Cultivars. Am J Plant Physiol. 7 (6): 269-275.

[40] TaIz, L., ZEIGER, E. (2002): Plant Physiology. 3rd Edn., Sunderland, Sinauer Associates, Inc.

[41] Tanveer, A., Tasneem, M., KhaliQ, A., Javaid, M.M., Chaudhry, M.N. (2013): Influence of seed size and ecological factors on the germination and emergence of field bindweed (Convolvulus arvensis). Planta daninha [online]. 31 (1): 39-51.

[42] Theerakulpisut, P., Bunnag, S., Kong-Ngern, K. (2005): Genetic diversity, salinity tolerance and physiological responses to $\mathrm{NaCl}$ of six rice (Oryza sativa L.) cultivars. Asian J. Plant Sci. 4 (6): 562-573.

[43] UnGAR, I.A. (1991): Ecophysiology of vascular halophytes. Boca Raton, FL: CRC Press.

[44] United States SAlinity LABORATORY STAFF (1954): Diagnosis and improvement of saline and alkali soils. US Department of Agriculture, Agricultural Handbook No. 60. Washington: US Government Printer.

[45] Vijayvargiya, S., Kumar, A. (2011): Influence of Salinity Stress on Plant Growth and Productivity: Salinity stress influences on plant growth. Germany. Lap Lambert Academic Publishers. pp. 170.

[46] WILD, A. (2003): Soils, land and food: managing the land during the twenty-first century. Cambridge, UK: Cambridge University Press.

[47] Xu, X.Y., FAn, R., Zheng, R., LI, C.M., YU, D.Y. (2011): Proteomic analysis of seed germination under salt stress in soybeans. J Zhejiang Univ Sci B. 12 (7): 507-517.

[48] Zaif, K., Amjad, M., Pervez, M.A., IQbal, Q., Rajwana, I.A., Ayyub, M. (2009): Evaluation of Different Growth and Physiological Traits as Indices of Salt Tolerance in Hot Pepper (Capsicum annuum L.). Pak. J. Bot. 41 (4): 1797-1809. 
[49] ZHANG, H., ZHAO, Y. (2011): Effects of different neutral and alkaline salinities on seed germination and early seedling growth of maize (Zea mays L.). Afr. J. Agril. Res. 6 (15): 3515-3521.

[50] ZHU, J.K. (2001): Plant salt tolerance. Trends Plant Sci. 6: 66-71. 